\title{
THE GEOGRAPHIC VARIATION OF \\ POLISTES (Megapolistes subg. n.) ROTHNEYI CAMERON
}

\author{
by \\ J. VAN DER VECHT \\ Division of Systematic Zoology, Leiden University, \\ c/o Rijksmuseum van Natuurlijke Historie, Leiden
}

The species discussed in this paper has been generally misidentified by previous authors. BinchaM (1897) and Dover $(1929,1931)$ confused it with the closely related $P$. hebraeus $(\mathrm{F}$.) (a junior synonym of $P$. olivaceus (DeGeer)). Bequaert correctly separated this species from its close relatives $(P$. olivaceus and $P$. jadwigae Dalla Torre), but unfortunately he did not publish his conclusions. Specimens in various collections have been labelled by him as $P$. jokahamae Radoszkowski, 1887, a name that has also been used by Japanese authors (SonAN, 1943; TsunExi, 1957, 1962; YoshiKawa, 1962; mostly emended as "yokohamae"). The original description of $P$. jokahamae, however, does not apply to the present species and leaves no doubt that Radoszkowski's species must be regarded as a synonym of $P$. japonicus Saussure, 1858. The oldest available name for our species appears to be $P$. rothneyi, proposed in 1900 by $P$. Cameron for a male Polistes from Barrackpore, Bengal. In the same paper Cameron described the female from Assam, but he did not recognize it as being conspecific with rothneyi and called it rufolineatus.

Polistes rothneyi belongs to a group of closely related species which appears to deserve subgeneric rank. The name proposed here for this group is taken from Dr. J. Bequaert's unpublished notes, now preserved in the U.S. National Museum and kindly made available to me by Dr. Karl V. Krombein.

Megapolistes, subg. $\mathrm{n}$.

Clypeus of $q$ wider than long, not extending above a line through the tentorial pits; face of male conspicuously flattened, its clypeus not or only very slightly extending above the level of the tentorial pits. Oculo-malar space of $q$ fairly long, but not longer than the length of the fourth antennal segment (more than 1/1/2 times the length of this segment in subg. Gyrostoma Kirby). Mandibles of $\hat{\delta}$ quadridentate (tridentate in subg. Gyrostoma Kirby); the basal (inner) tooth broader than the others and more directed inwards.

Thorax more or less shiny, often with distinct puncturation (dull and with coriaceus sculpture in subgenera Polistes Latreille and Sulcopolistes Blüthgen). Pronotum on each side with a small pit or fovea in front of the transverse carina. Mesepisternum with transverse suture and with epicnemial carina, with pronounced impression in front of the mid coxae. Hind trochanters of $\delta$ normal (bearing tooth in subg. Gyrostoma Kirby). Parastigma of the forewing not longer than the stigma.

Transverse ridge of first gastral sternite blunt, situated right below the end of the muscular slit of the tergite. Seventh gastral sternite of $\delta$ with a pair of tubercles (blunt and low in P. tenebricosus) or apophyses close to the apical margin.

Type species: Polistes olivaceus (DeGeer, 1773) $(=$ hebraeus $(\mathrm{F} ., 1787)=$ undatus (Oliv., 1791) $=$ macaensis (F., 1793)).

Some other species belonging to this subgenus are: P. balder Kirby, 1888; diabolicus Sauss., 1853; jadwigae Dalla Torre, 1904 (= japonicus Cam., 1900, nec Sauss. $=$ perkinsi Kohl, $1908=$ okinawensis Mats. \& Uch., 1926 = tahitensis Cheesm., 1928); rothneyi Cam., 1900; schach (F., 1781); tenebricosus Lep., 1836; tepidus (F., 1775); wattii Cam., 1900.

The species of the subgenus Megapolistes are inhabitants of Eastern Asia, the Oriental and the Australian regions; a few species have recently become established in Madagascar, the Seychelles, and in many islands in the Pacific Ocean.

P. rothneyi has been frequently confused with the closely allied species olivaceus and jadwigae (usually misspelt fadwigae or fedwigae by Japanese authors). Its more important characters are as follows: 
$q$ - Lower part of genal carina sharp, the transition gena-postgena distinctly angular close to the mandibles. Mesepisternum distinctly punctate, with well defined punctures. Punctures in upper part of lower half of metapleura well defined (in P. jadwigae these punctures not sharply margined and more superficial). Propodeum with sharp striae which almost reach the sides (the striae laterally indistinct in $P$. jadwigae). Antennae ferruginous, as a rule at least the basal segments blackish dorsally. Basal $2 / 3$ to $3 / 4$ of hind metatarsus usually fuscous or black.

$\hat{\delta}$ - Eyes not separated from clypeus. Apophyses of seventh gastral segment much longer than wide, not densely pubescent as in $P$. wattii Cam. and not flattened at apex and spatulate as in $P$. olivaceus. Apical antennal segment distinctly flattened, slightly wider than the twelfth segment.

Length to end of second gastral tergite: $16-20 \mathrm{~mm}$.

Polistes rothneyi is a polytypic species, which in its extensive area of distribution shows a very interesting variation in colour pattern. In the available material no less than 18 different colour forms can be distinguished. They are treated here as subspecies, with the exception of two forms which are represented by a single specimen only (figs. 7 and 8). Since is it not only difficult and tedious, but also rather unsatisfactory to describe the colour patterns in words, I have preferred to show the geographic variation in a series of diagrams. The colours of these wasps range from paler or darker yellow through various shades of brownish red to black. In the figures prepared by Mr. H. Heijn the successive tints in this range are indicated by various degrees of shading. When comparing specimens with these figures, however, it should be kept in mind that particularly the yellow and red colours of the abdomen may be abnormally dark in poorly preserved specimens.

In the majority of the subspecies the pattern consists of yellow and black, the most extreme forms being subspp. yayeyamae (fig. 13) and helvenacus (fig. 19) which are mainly yellow, and Psubsp. A (fig. 7) in which the yellow markings are much re-

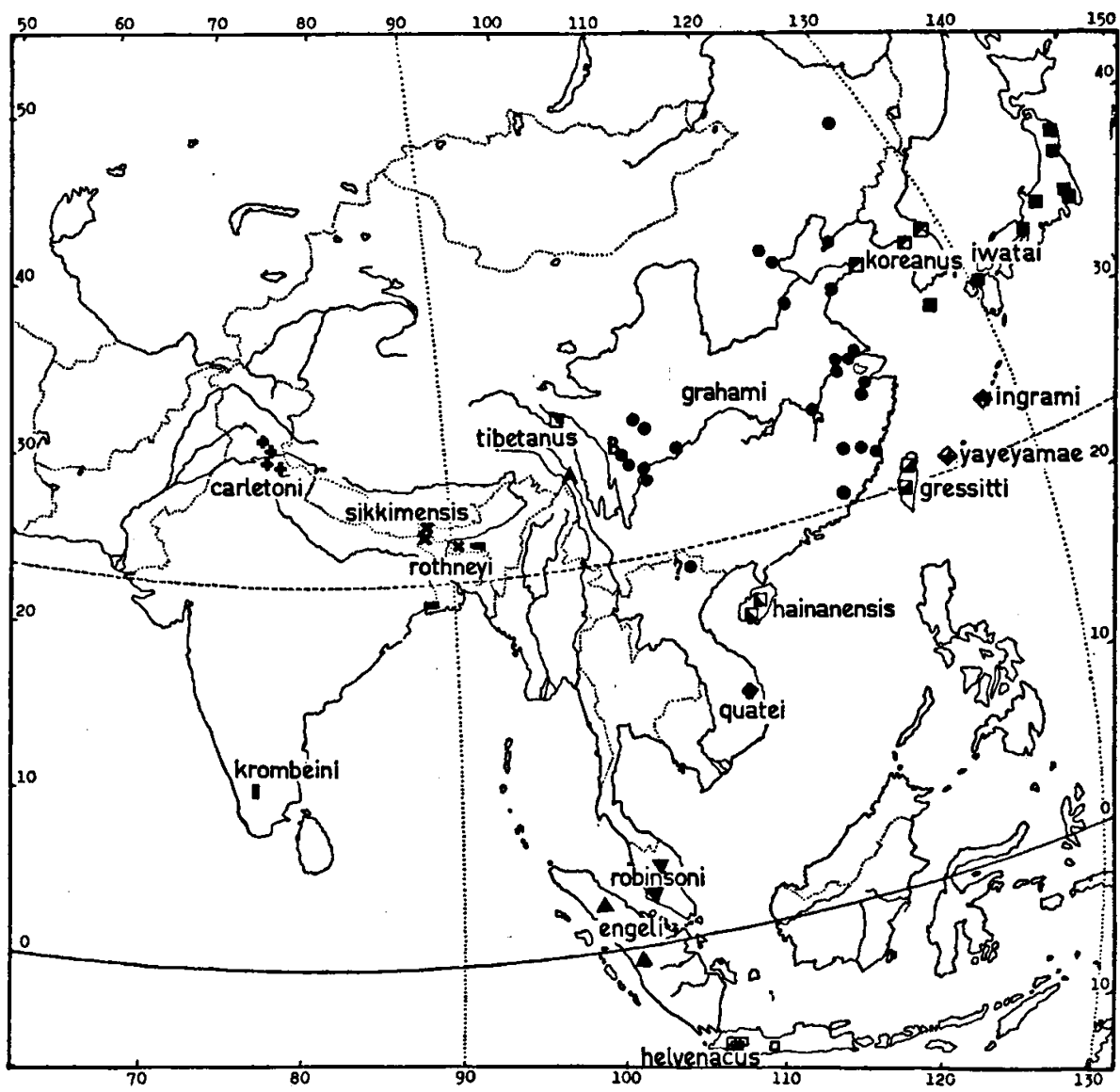

Fig. 1. Distribution of the subspecies of Polistes rothneyi Cameron. 
duced. In another group of subspecies (figs. 3-5, 6, 8, and 18) the ground colour is brownish red; here the extremes are the entirely red subsp. carletoni (fig. 3) and the strongly melanistic subsp. engeli (fig. 18). Some forms are more or less transitional; in the subspp. ingrami (fig. 12) and robinsoni (fig. 17) the yellow markings are partly replaced by red, and subsp. sikkimensis (fig. 5) has a distinctive pattern with both red and yellow elements.

It is noteworthy that the forms of the second group are all mountain inhabitants; they appear to be restricted to the Himalayas and the mountain range of Sumatra. The distribution of the various forms (fig. 1) clearly shows, however, that in general there is no evident climatic regularity in the geographic variation of this species. The inhabitant of the West and Middle Javan mountain forests is much more brightly coloured than the subspecies engeli and robinsoni which live under very similar climatic conditions in Sumatra and Malaya, respectively. The difference between the subspp. ingrami and yayeyamae, both inhabiting some islands of the Ryukyus, is also remarkable in this respect.

Our material is not sufficiently complete to say much about the possible occurrence of intergradation between the subspecies. Seven subspecies are island inhabitants and these will almost certainly prove to be separated from the neighbouring forms by more or less distinct gaps. As regards the continental subspecies, it seems probable that much depends on the degree of ecological isolation. For several forms it is certain that they are forest inhabitants, so that at least nowadays some populations may be separated from others by stretches of open country. So far as I know, however, nothing has been published about the ecological requirements of the Northern subspecies. It is therefore uncertain whether this phenomenon plays a role in the separation of such forms as grahami and its various neighbours. Without doubt interesting results could be obtained if collectors in Asia would pay special attention to this subject.

The material used for this study is the property of several museums and of a few private collectors; the museum collections are listed below, together with the abbreviations used in this paper.

\footnotetext{
AMNH $=$ American Museum of Natural History, New York, U.S.A.

BISH = Bernice P. Bishop Museum, Honolulu, Hawaii, U.S.A.

BM = British Museum (Natural History), London, England.

CAS = California Academy of Sciences, San Francisco, Calif., U.S.A.
}

CU = Cornell University, Dept. of Entomology, Ithaca, N.Y., U.S.A.

LACM $=$ Los Angeles County Museum, Los Angeles, Calif., U.S.A.

MCG = Museo Civico di Storia Naturale, Genova, Italy.

MCZ = Museum of Comparative Zoology, Harvard Univ., Cambridge, Mass., U.S.A.

ML = Rijksmuseum van Natuurlijke Historie, Leiden, Netherlands.

MP = Muséum d'Histoire Naturelle, Paris, France.

MZB = Museum Zoologicum, Bogor, Indonesia.

OUM = Oxford University Museum, Oxford, England.

UMMZ = University of Michigan, Museum of Zoology, Ann Arbor, Mich., U.S.A.

USNM = United States National Museum, Washington D.C., U.S.A.

This paper is the third of a series of studies on IndoAustralian wasps which includes the results of investigations on the material preserved in various American Museums. 1)

Key to the colour forms of Polistes rothneyi Cameron

1. Mesoscutum yellow or brown, usually with narrow black band at hind margin and often with three narrow dark lines on the disk (figs. 3, 8, 19).

2

- Mesoscutum black, with or without two or four yellow or red lines (in some Himalayan specimens the two lines on each side confluent).

2. Mesoscutum yellow, with some more or less distinct black lines. - Java. helvenacus subsp. $n$

- Mesoscutum brown or brownish red. 3

3. Thorax brown, with some dark lines along the sutures and on the propodeum. Gaster reddish brown, first and second gastral tergites narrowly black at the base. Head brown, with only faint blackish markings behind posterior ocelli. - N.W. India.

carletoni subsp. $\mathbf{n}$.

- Mesepisternum black, marked with brown anteriorly, metapleura, postscutellum and propodeum black. First gastral tergite black, brownish at extreme apex, the second tergite blackish, with two transverse blotches on disk and a band at apical margin dull red. Head brown-red; vertex with black band across ocelli. - Yachow, Szechwan (1 \&). ?subsp. B

4. Mesoscutum black, rarely with two short indistinct lines. - Korea; Okinawa; Himalayas.

5

- Mesoscutum black with two or four yellow or red lines.

8

5. Pronotum black (rarely partly red), with narrow yellow line along transverse carina and at posterior margin. Gastral tergites 2-6 black with broad irregular yellow bands at posterior margins. - Korea.

koreanus subsp. $\mathbf{n}$.

- Pronotum at least partly rufous.

6

6. Thorax black, except for the tegulae and part of the

1) This work was supported by NSF-grant GB - 660 (201 D - 308); see J. van der Vecht, 1966, The EastAsiatic and Indo-Australian species of Polybioides Buysson and Parapolybia Saussure. - Zool. Verh. Leiden, 82. 
pronotum; gastral segments 1-3 almost entirely black. - S.E. Tibet. ?subsp. A

- Scutella partly rufous; abdomen different. 7

7. Hind femora black, reddish at apex only. Gastral segments 2-6 mainly rufous. - Tibet.

tibetanus subsp. $\mathbf{n}$.

- Apical half of hind femora mainly reddish, or reddish and yellow. Gastral tergites 2-5 with yellow or reddish yellow apical band, 2 with reddish band at base. - Okinawa.

ingrami subsp. $\mathrm{n}$.

8. At least the dorsal surface of the pronotum yellow; the sides yellow to orange-yellow, sometimes with some fuscous blotches at ventral margin.

- Dorsal surface of pronotum at least partly reddish brown and/or fuscous to black.

14

9. Mesoscutum with two yellow lines. - Japan; Quelpart I. iwatai subsp. $\mathrm{n}$.

- Mesoscutum with four yellow lines (rarely 2, in small specimens).

10

10. Propodeum yellow, with a black band at the base (dilated laterally) and a dark median line. Femora and tibiae mainly yellow. - Southern Ryukyu Is.; Formosa (?).

yayeyamae Matsumura

- Propodeum with more or less distinct black lines separating the lateral and the median yellow spots. At least the hind legs more extensively black. 11

11. Mesepisternum with large yellow mark in front of epicnemial carina. Only the first and second antennal segments somewhat infuscated dorsally. Coxae II mainly yellow; femora II black on basal third only. - India.

krombeini subsp. $\mathrm{n}$.

- Mesepisternum black anteriorly or with only a small spot anteriorly in upper part. Coxae II mainly black.

12. Second gastral sternite black with yellowish posterolateral spots or with widely interrupted apical band. - Indo-China. quatei subsp. $n$.

- Second gastral sternite with wide apical yellow band.

13. Sides of pronotum entirely yellow. Apical yellow band of first gastral tergite at least partly interrupted (always?). - Formosa. gressitti subsp. $n$.

- Sides of pronotum partly black or blackish. Apical band of first gastral tergite not interrupted. - Hainan. hainanensis subsp. $\mathbf{n}$.

14. Propodeum black; first gastral tergite black or red with black markings.

- Propodeum with yellow or reddish markings; first gastral tergite with yellow band at posterior margin.

16

15. Second and third gastral sternites black with reddish mark on each side. Scutellum and postscutellum black, the former somewhat reddish laterally. First gastral tergite black, with more or less distinct, narrow, reddish posterior margin. Mid and hind legs almost entirely black. - Sumatra. engeli subsp. $n$.

- Second and following gastral sternites red, at most somewhat blackened at the base. Scutella mainly red. First gastral tergite red, the base and a narrow band at some distance from the posterior margin black. Mid and hind femora and mid tibiae with extensive red markings. - Bengal; Assam.

rothneyi Cameron

16. Mesoscutum with four reddish or yellowish lines, the lines on each side sometimes confluent. Head reddish with black band across the ocelli. Second to fifth gastral tergites reddish at base, yellowish beyond the faintly indicated waved line; the second tergite moreover with irregular black band at base. sikkimensis subsp. $\mathbf{n}$.

- Mesoscutum as a rule with only two yellow lines; if lateral lines are present, they are short and narrow. Vertex usually black with two transverse yellow marks behind the ocelli, rarely as above. Waved line of second gastral tergite black and distinct. 17

17. Dorsal surface of pronotum yellow, normally with elongate wedge-shaped black spot. Hind femora and tibiae black with some yellow markings. Second gastral sternite as a rule with yellow band at posterior margin. Scutellum usually entirely yellow. Sides of thorax with four or five large yellow spots (in dark specimens the lower metapleural spot absent). - China (for specimens from Hainan Island see under 13).

grahami subsp. $\mathbf{n}$.

- Dorsal surface of pronotum reddish, sometimes fuscous anteriorly, with narrow yellow lines along transverse carina and at posterior margin. Hind femora and tibiae black. Second gastral sternite almost entirely black. Scutellum as a rule partly black. Sides of thorax with fewer yellow markings. - Malaya. robinsoni subsp. $\mathbf{n}$.

Polistes rothneyi krombeini subsp. $\mathrm{n}$. (fig. 2)

$q$ - Characterized by the extent of the yellow markings, as indicated in the key and shown in the figure. This subspecies agrees with the Javan race in having large yellow marks on the mesepisternum, in front of the epicnemial carina; however, the mesoscutum is darker and the legs are brighter than in that form. The dark lines separating the median and lateral yellow lines of the mesocutum are reddish in the type, but reddish and black or entirely black in the paratypes.

The distribution of subsp. krombeini deserves further study. Two males from Kumaon are provisionally placed here, because they show a general agreement in colour pattern. The mesosternum is almost entirely yellow, but the legs somewhat different: mid and hind femora are yellow ventrally, and mainly or entirely black above (mid femora with yellow stripe at apex), the hind tibiae are black with a yellow line on the ventral side.

India: 1 \& Coimbatore, 1950, P. Susai Nathan (type, coll. Krombein); 3 Coimbatore, May 1951, P. Susai Nathan (paratypes, MCZ; 1 q ML); 2 o Kumaon, Genesh Ganga, $14.400 \mathrm{ft}$., 16 July 1958, F. Schmid (ML).

Polistes rothneyi carletoni subsp. n. (fig. 3)

ㅇ - Almost uniformly reddish brown, with a few, somewhat variable, black or blackish markings as indicated in the figure. Clypeus, lower part of frons 


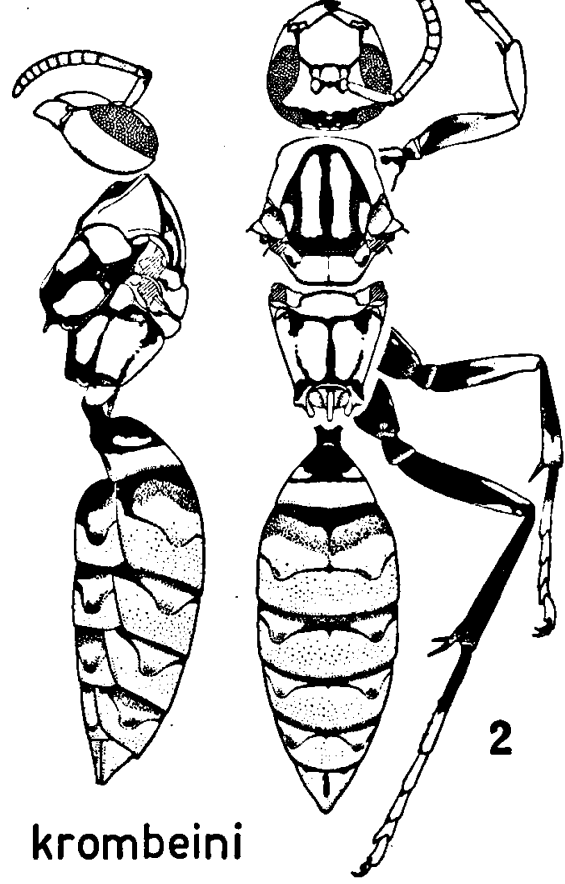

Fig. 2. P. rothneyi krombeini subsp. n., 우 (S. India, Coimbatore, type, coll. Krombein).

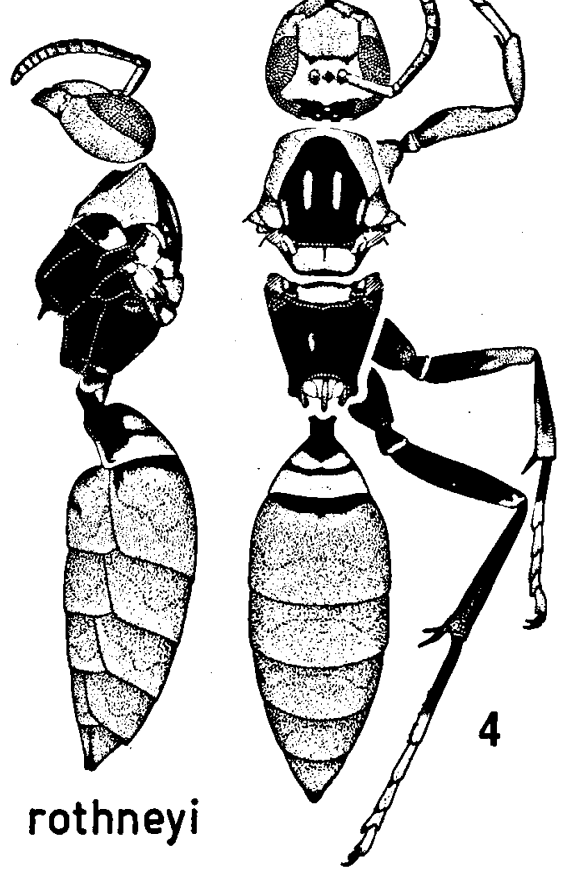

Fig. 4. P. rothneyi rothneyi Cam., (India, Assam, ML).

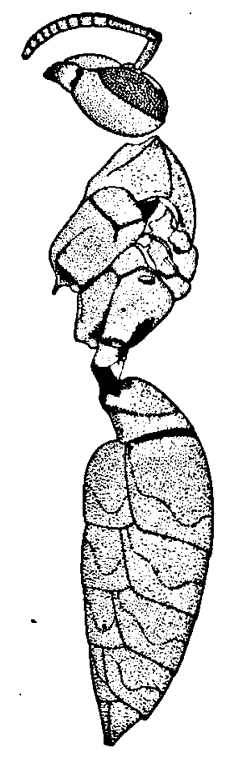

\section{carletoni}

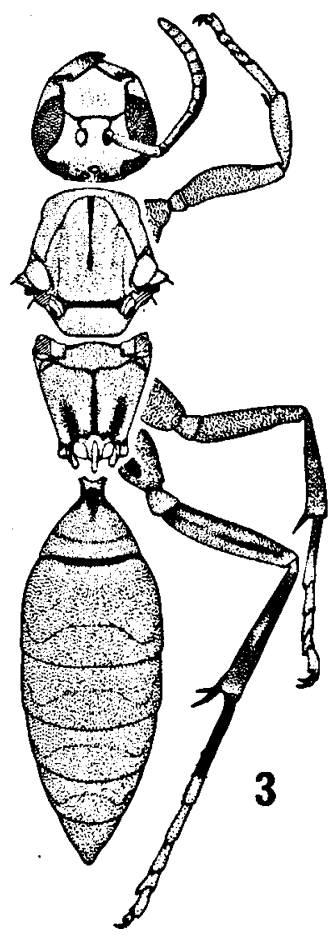

Fig. 3. P. rothneyi carletoni subsp. n., 우 (N.W. India, Kooloo, type, USNM).

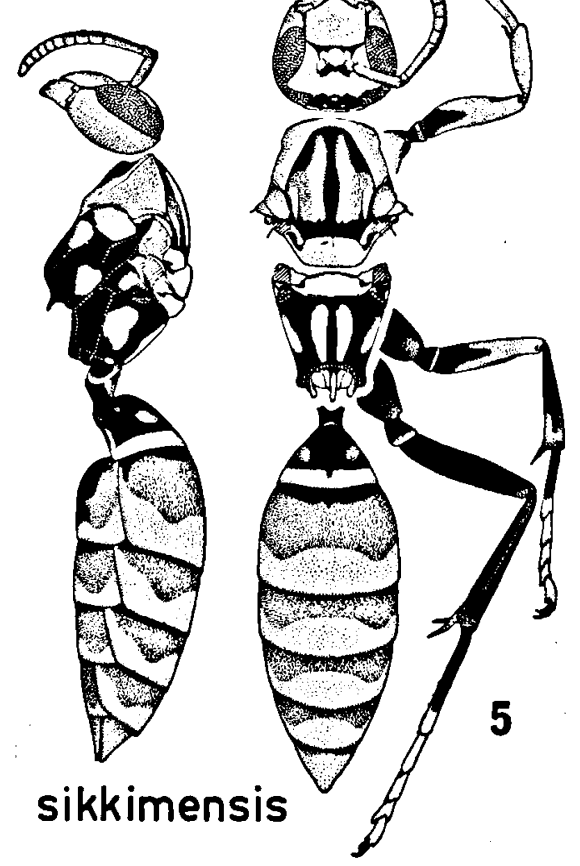

Fig. 5. P. rothneyi sikkimensis subsp. n., ф (India, Sikkim, paratype, BM). 
and part of the temples somewhat yellowish. Vertex with a slightly darker brown band across the ocelli; this band bordered posteriorly by an irregular blackish line. Fore tarsi brownish yellow, the basitarsus darker at the base; mid and hind tarsi yellow, except for the fuscous to black proximal two thirds to three fourths of the basitarsus. Wings pale brown with yellowish tinge.

The type is a 9 from Kooloo (USNM); the other females recorded below are paratypes.

India: 11 \% Kooloo (= Kulu, North of Simla), leg. M.M. Carleton (USNM); 14 " "Kashmir" and Simla, 5000-6000 ft., April 1901, coll. C. G. Nurse (BM); 2 Kashmir, 5000-6000 ft., May 1901 (USNM). Kumaon, 2 o, W.Almora, H. G. C. (BM); body with more extensive black markings: a median line and irregular lines at margins and along parapsidal furrows of mesoscutum, parts of mesepisternum and propodeum, lines on femora and on mid and hind tibiae; antennae ferruginous, with black line on first and second segments and extreme base of third; flattened part of apical segment also black.

\section{Polistes rothneyi rothneyi Cameron (fig. 4)}

Polistes rothneyi Cameron, 1900, Ann. Mag. nat. Hist. (7) 6: 410, ô - "Barrackpore, Bengal" (coll. Rothney, OUM).

Polistes rufolineatus Cameron, 1900, Ann. Mag. nat. Hist. (7) 6: 411, $q \delta$ - "Khasia Hills, Assam", coll. Rothney [BM; lectotype by present designation $=q$ no. 18.895a (Cam. coll. 1901-137); a second syntype ${ }^{+}$, no. $18.895 \mathrm{~b}$, is $P$. jadwigae Dalla Torre; a $\hat{\delta}$ under this name in OUM is a form of $P$. japonicus Sauss.].

$q$ - Similar to subsp. carletoni, but a band across the vertex, the greater part of the thorax, the base of the first gastral tergite, the first gastral sternite, an irregular band at the base of the second tergite, a blotch at the base of the second sternite, and part of the legs, black. Coxae and trochanters black, fore coxae reddish anteriorly, femora etc. as shown in the figure.

The females recorded below all have the propodeum entirely black, but in the male type there are two reddish markings on the dorsal surface and one on each side. Unfortunately the available material does not permit to ascertain whether this pattern may also occur in the females.

India: Assam, $1 q$ Khasia Hills (type of $P$. rufolineatus Cameron, BM, no. 18.895a); 5 \% Shillong, 6 Aug. 1903 (BM; 2 Q ML); 1 "Assam” (ML). Bengal, 1 đo Barrackpore (type of $P$. rothneyi Cameron, OUM).

Polistes rothneyi sikkimensis subsp. n. (fig. 5) o - Antennae somewhat variable; in the type they are entirely ferruginous, in the paratypes the segments 3-5 are moderately infuscated dorsally; the specimen from Sikkim also has a small dark spot at the base of the second segment. The lines on the mesoscutum yellowish in the Sikkim specimens, almost entirely ferruginous in the females from Darjeeling. Scutellum and postscutellum yellow, with brownish tinge, the former with ill-defined ferruginous blotch posteriorly. The females from Darjeeling have the apical bands of gastral tergites 2-5 less distinctly yellow (more reddish) than the other specimens, but this may be due to their state of preservation. In all specimens the mid femora are ferruginous, rather narrowly black at the base, and somewhat yellowish at extreme apex.

India: Sikkim, 1 \% Runjit Valley, $1000 \mathrm{ft}$. , April 1894, coll. C. T. Bingham, 96-30 (type, BM); 1 q "Sikkim", Swale Coll., 1919-120 (paratype, BM); 1 \% "Sikkim" (Mus. Calcutta). - West Bengal, 19 Darjeeling, 1891, leg. Möwis, from R. Oberthür (paratype, ML); 1 \& Darjeeling, April 1894, Bingham coll., "P. sulcatus Sm." (BM). - Assam, 1 W. F. Badgley (BM, no. 1906-185); 1 우 Khasia Hills (BM, no. 96-35).

Polistes rothneyi tibetanus subsp. $\mathrm{n}$. (fig. 6)

$q$ - Similar to subsp. carletoni, but a band across the vertex, the greater part of the thorax, the base of the abdomen and certain parts of the legs black. Wings as in subsp. carletoni.

The drawing is made from a paratype (AMNH) which agrees well with the type; in the latter the basal black band of the second gastral tergite is slightly wider.

This form differs from typical rothneyi mainly in the absence of red lines on the mesoscutum.

Tibet: 9 S S.E. Tibet, Dzogang, 9-14.000 ft., 1-21 Sept. 1936, R. J. H. Kaulback (type and paratypes, BM, 1937547); 2 ᄋ Tibet prov., F. 4722 (paratypes, AMNH; ML).

\section{Polistes rothneyi Psubsp. A (fig. 7)}

This form is remarkable for having the anterior three gastral segments almost entirely black, whereas the posterior three are extensively marked with yellow.

The single available female bears a label: "Vallee du Mékong Tibetain et massif montagneux entre le Mékong et la Salouen (28-30 lat.) J. Bacot, 1908" (MP).

\section{Polistes rothneyi ?subsp. B (fig. 8)}

Among the numerous specimens of $P$. rothneyi grahami collected by D. C. Graham in the Chinese province of Szechwan, I found one aberrant female which appears to be rather close to subsp. tibetanus. 

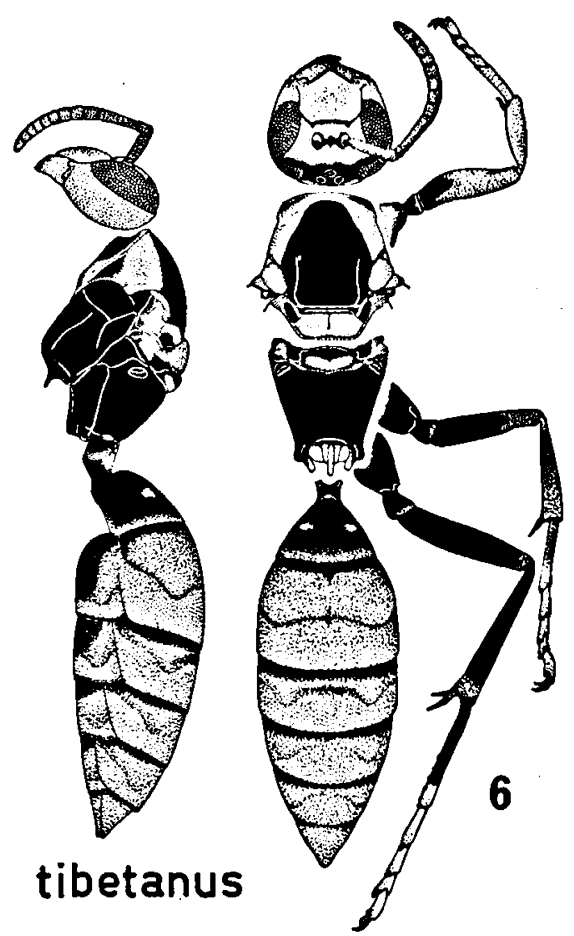

Fig. 6. P. rothneyi tibetanus subsp. n., ㅇ (Tibet, paratype, AMNH).

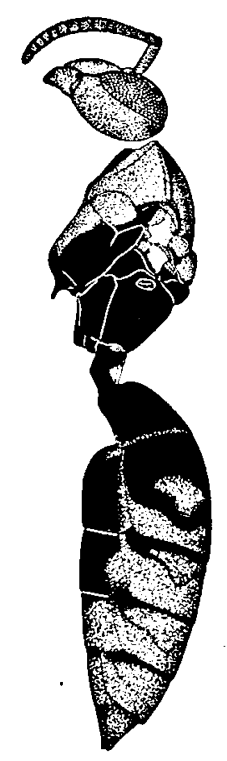

? subsp. B

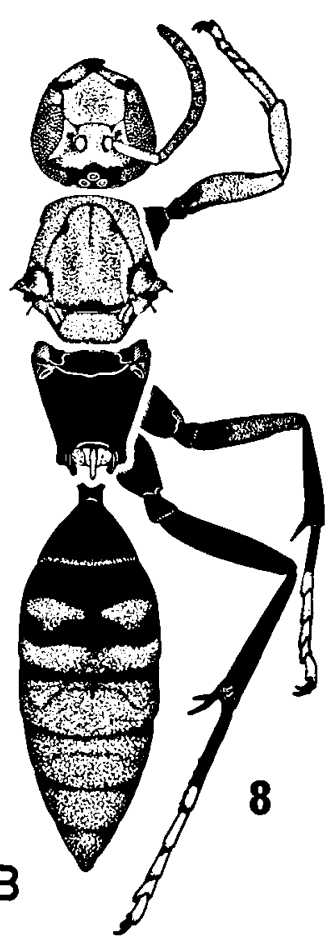

Fig. 8. $P$, rothneyi ?subsp. B (China, Yachow, USNM).

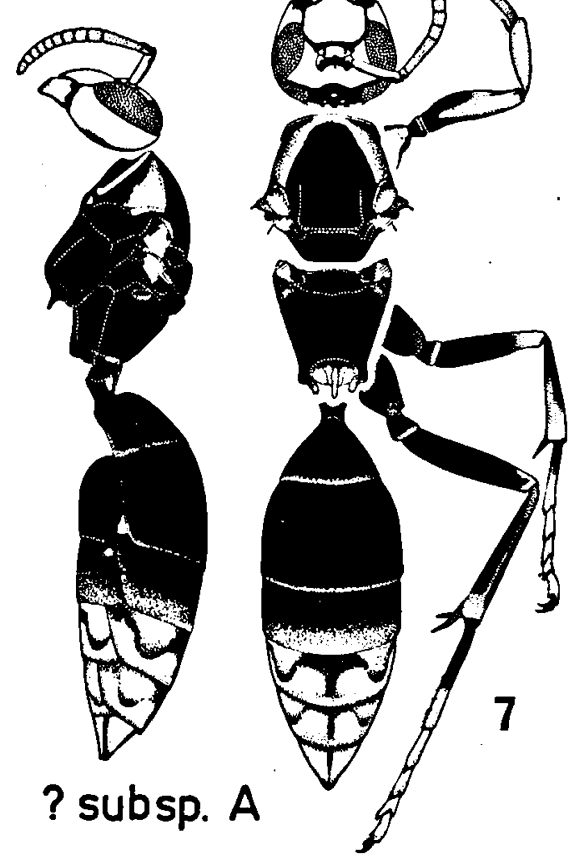

Fig. 7. P. rothneyi Psubsp. A, $q$ (Mekong, $\left.28-30^{\circ} \mathrm{N}, \mathrm{MP}\right)$.

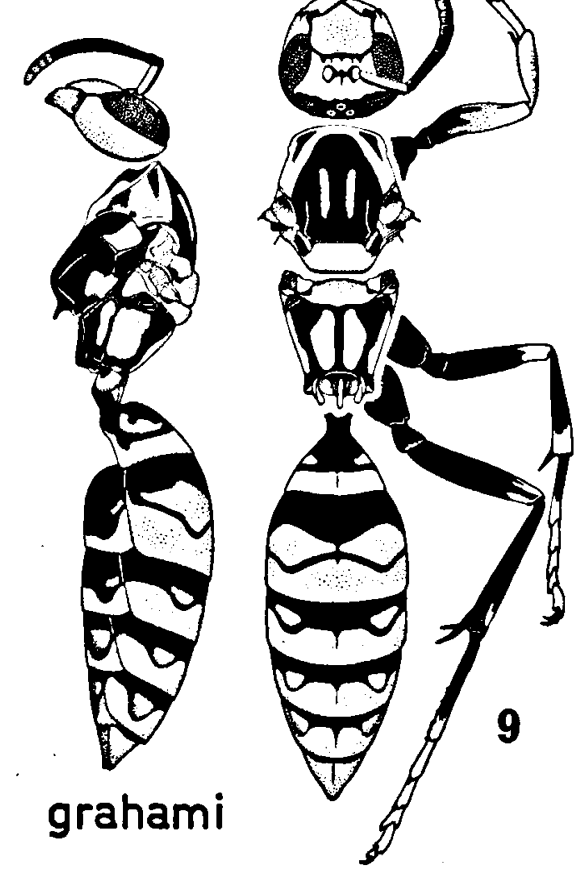

Fig. 9. P. rothneyi grahami subsp. n., 우 (China, Hangchow, type, USNM). 
As it comes from a locality where the subsp. grahami has also been collected, it appears doubtful whether this specimen represents a subspecies.

The ground colour is brownish red, darker than in subsp. tibetanus; the distribution of the red and the black parts is shown by the figure. Wings as in the preceding forms.

China: Szechwan, 1 \& Yachow, 1925, D. C. Graham (USNM).

Polistes rothneyi grahami subsp. n. (fig. 9)

Q - The colour pattern of the Chinese subspecies, as shown in the figure, appears to be remarkably uniform throughout its extensive area of distribution. The characteristic black mark on the dorsal surface of the pronotum varies somewhat in size, but was never entirely absent in the numerous specimens examined by me. As a rule the vertex is black, with the usual two transverse yellow marks behind the ocelli; in only a few specimens from Szechwan these marks are coalescent, and also connected with the yellow areas behind the eyes. Mesoscutum usually with two yellow lines, but fairly often with an additional short line near each tegula. Apical band of first gastral tergite as a rule more or less deeply incised in the middle anteriorly. In some specimens from Fukien the black area of the second sternite reaches the posterior margin.

$\delta$ - Colour pattern very similar to that of the female, but mesosternum in front of the epicnemial carina yellow, and the legs much paler: all coxae, trochanters, femora and tibiae nearly entirely yellow on ventral side. Apical antennal segment black. Scutellum often (P) with median black line.

The type is a female from Hangchow, 15 July 1925, M. A. Jaynes (USNM).

China: Manchuria, 1 q Dairen, Waymarn (MCZ), 19 Harbin, Aug. 1935, Skrortzov (MCZ) (slightly darker than specimens from C. and S. China; in the $O$ from Dairen the spots on tergite 2 rather small). - Hopeh, 8 Q Peking, Aug. 1921 (AMNH); 3 ㅇ 4 o Peking, Aug. 1932, G. Liu (MCZ); 1 o 1 of Peking, Sept. 1928, N. Gist Gee (USNM); 1 ㅇ Tientsin, Oct. 1930, M. L. Robb (USNM). - Shantung, 1 \& Tsinan, 29 April 1911, A. P. Jacot (USNM); 2 Tsingtau, July and Sept., Hoffmann (MCZ). - Szechwan, many localities, up to $5000 \mathrm{ft}$. incl. Chungking, Chengtu, Kwanhsien, Yaan (Yachow), Hanyuan (Fulin), Mt. Omei, Ipin (Suifu), Kingfu, mainly collected by D. C. Graham (10 $q$ CU; 11 1 ơ MCZ; 85 क 14 ô USNM). - Hupeh, 1 \& Sze Sang, Gressitt and Djou (CAS). - Anhwei, 2 우 2 ô Kinhua Shan, Sept. 1932, G. Liu (MCZ). - Kiangsu, 1 @ Nantung, 9 May 1923, E. C. Van Dyke (CAS); 6 \& Nanking, 24 June 1923, W. E. Macklin (CAS); 2 q Chinkiang, 31 July 1924, J. F. Illing- worth (USNM); 1 \% Maan Chi Shan, Oct.-Dec. 1921, C. W. Howard (USNM). - Kwangtung, 6 \& Meihsien and environs, June 1936, L. Gressitt (MCZ). - Kiangsi, I $\delta$ Kuling, N. Gist Gee (USNM), 1 \& 1 o "Kou Ling" (? = Kuling), July 1918 and July-Aug. 1919, J. Hervé Bazin (MCZ). - Fukien, 5 \& Foochow, 1935-6, M. S. Yang (BM; $2 q$ ML); 3 F Foochow, 14 May 1925, C. C. Woo (USNM), 4 우 Foochow, July 1926; C. R. Kellogg (CAS; MCZ); 2 ㅇ Nanping (Yen Ping), 31 Aug. 1920 (AMNH); 10 \& Kuatun, March and April 1946, Tschung Sen (coll. P. M. F. Verhoeff; ML); 16 Kuatun, 27.40 N., 117.40 E., 2300 m, 1 April-23 July 1938, J. Klapperich (Zool. Mus. Bonn; 3 \& ML). - Chekiang, 1 \% Hangchow, 15 July 1925, H. A. Jaynes (type, USNM); 3 市 Hangchow, Aug. 1925 and April 1926, T. P. Chao (USNM); 2 ㅇ Tunglu, 23-24 April 1926, Mrs. E. Wright (CAS).

Polistes rothneyi koreanus subsp. n. (fig. 10)

$q$ - The black area between the tops of the eyes is broadly connected with the black occiput; it is marked by two short transverse reddish lines behind the ocelli. The markings of thorax and abdomen of the paratype from Seoul are slightly less extensive than those of the type.

Korea: 2 Seoul area, 25 April 1954, G. W. Byers (type, UMMZ; paratype, ML); 3 Kwangnung, 25 Oct. 1955, Mi Sung Woo (USNM).

China: 1 @ Weihaiwei, T. B. Fletcher (BM, no. 1900100).

Polistes rothneyi iwatai subsp. n. (fig. 11)

Polistes yokohamae; Tsuneki, 1957, The Life Study, Fukui 3: 1-4 (Japan) [misidentification and erroneous spelling; not $P$. jokahamae Rad.]. - Yoshikawa, 1962, Bull. Osaka Mus. Nat. Hist. 15: 7; do., 1962, J. Biol., Osaka City Univ. 13: 41 (Japan).

$q$ - Very similar to subsp. grahami, but the pronotum yellow with at most a small black spot in the lateral angle; supraclypeal area black with small yellow spots; lines on mesoscutum often narrower; sides of thorax usually less extensively marked with yellow, lines on propodeum sometimes reduced or absent, first gastral tergite with at most two small spots in front of the apical band; area between basal band and waved line on tergite 2 often somewhat reddish.

The type is a female from Takayama, 13 Aug. 1930 (MCZ); the other specimens recorded below are paratypes.

Korea: 2 $q$ I $\hat{o}$ Quelpart I. (= Cheju Do), 3-8 Aug. 1955, C. W. Kim (USNM).

Japan: Kyushu, 1 \% Fukuoka, 23 Febr. 1929, Fujino and Matsuo (MCZ); 1 O do., June 1945, R. van der Veen (ML). - Honshu, 1 Sasayama, 16 May 1953, M. Miki, 


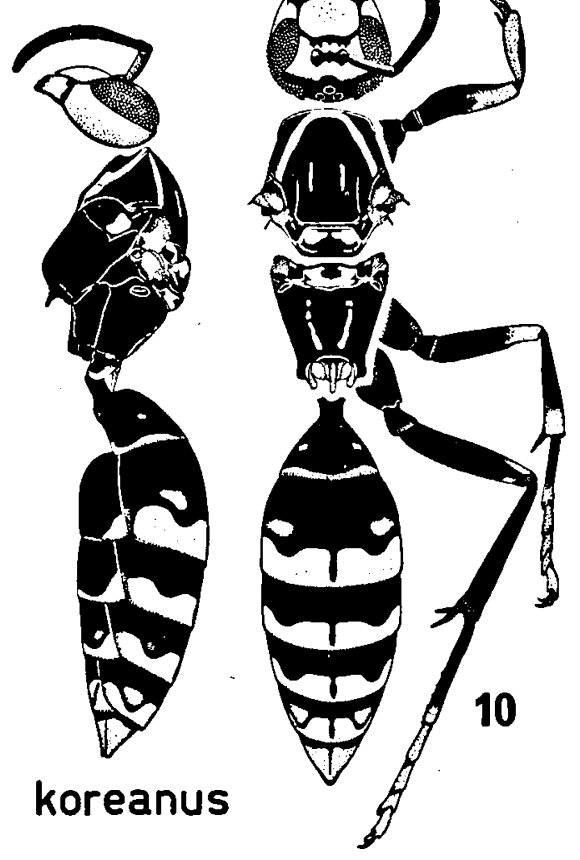

Fig. 10. P. rothneyi koreanus subsp. n., + (Korea, Seoul, type, UMMZ).
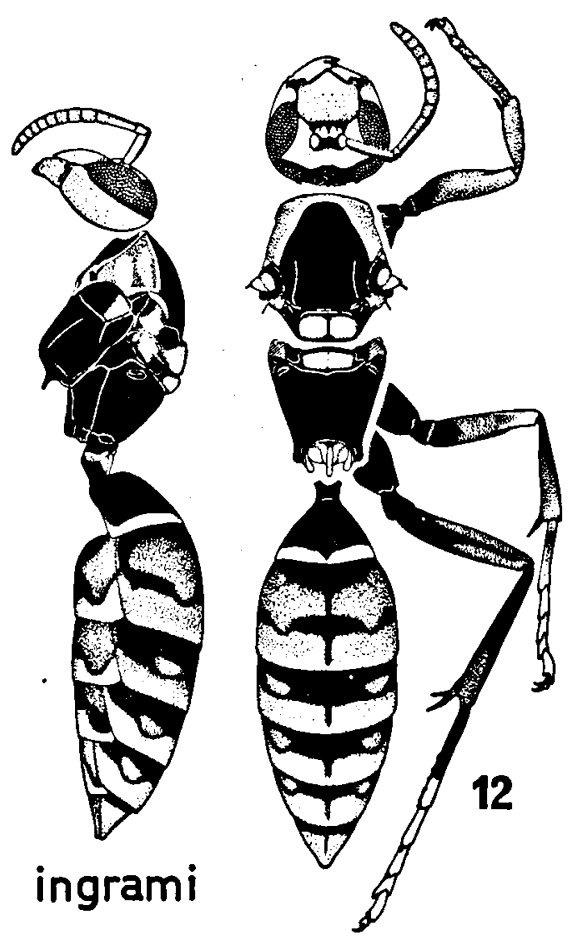

Fig. 12. P. rothneyi ingrami subsp. n., 우 (Okinawa, type, MCZ).
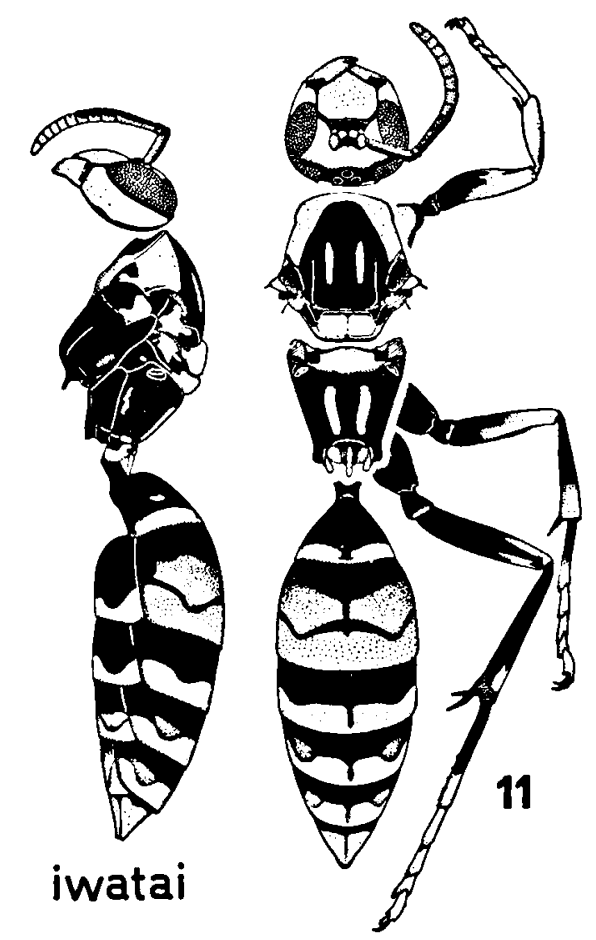

Fig. 11. P. rothneyi iwatai subsp. n., $\bigcirc$ (Japan, Tokayama, type, MCZ).
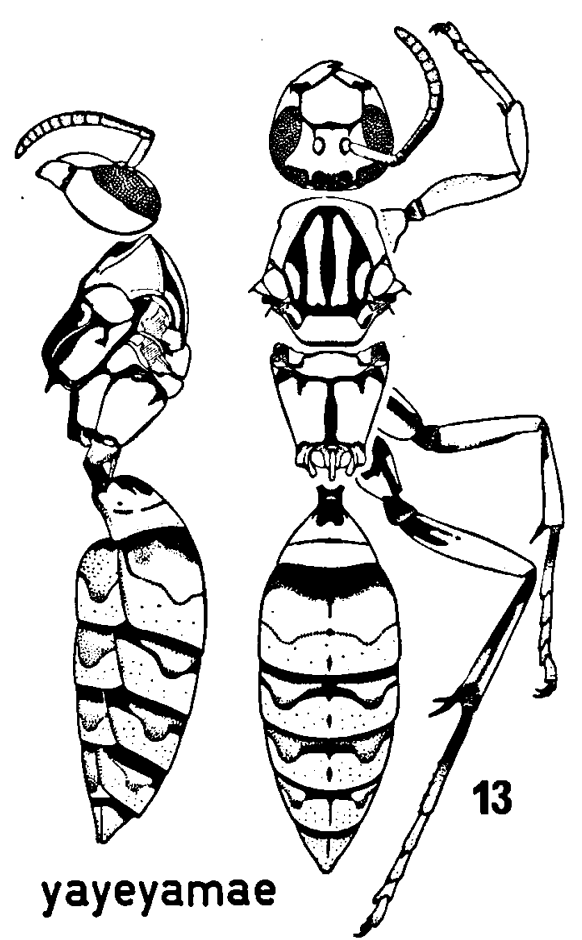

Fig. 13. P. rothneyi yayeyamae Mats., (Ryukyu Is., Iriomote, ML). 
from Prof. Iwata (ML); 2 q Takayama, 13 Aug. 1930 and 22 Aug. 1931, L. Gressitt (MCZ; ML); 3 ㅇ Tokyo, 1928 and April-June 1931, L. Gressitt (MCZ; ML); 1 \& Yokohama, leg. Koebele (CAS); 1 \& do., 6 June 1931, L. Gressitt (MCZ); 1 워 1 Sondai, May-Sept. 1926, Yamanaka (MCZ); 1 ㅇ Mijako, 1881, D. A. Isola (MCG).

Polistes rothneyi ingrami subsp. $\mathrm{n}$. (fig. 12)

ㅇ - Vertex as in subsp. koreanus: black with two transverse reddish lines behind the ocelli. The colour pattern appears to be fairly constant, the available specimens agreeing well with the figure of the type. The markings of the scutella vary from yellow (in the $q$ from Aha) to dark rufous (in most of the other specimens); the type is transitional.

The type is a female from Motobu Peninsula; the other specimens recorded below are paratypes.

Ryukyu Is.: Okinawa, 1 ㅇ Okinawa, 31 Aug. 1934, L. Gressitt (MCZ); 1 \& Motobu Peninsula, C. T. Parsons (type, MCZ); 1 \% Chizuka, July-Sept., 1945, R. L. Ingram (USNM); 5 q do., July-Sept. 1945, G. E. Bohart \& C. L. Harnage (Dept. Ent., Davis, Calif.; 2 o ML); 1 \& Aha, 18 May 1955, A. A. Hubert (USNM); 1 \% Kadena, A.F.B., 7 July 1962, S. M. Fullerton (LACM); 1 \& Yona, 8 July 1962, K. Okamoto (ML).

Polistes rothneyi yayeyamae Matsumura (fig. 13)

Polistes yayeyamae Matsumura, in Kuroiwa, 1908; Prov. List. Hym. Loochoo: 6 (without description).

Polistes yayeyamae Matsumura, 1911, Thous. Ins. Japan, Suppl. III: 106, "Q $\delta "$ " [but $\delta$ not described separatelyl], no. 673, pl. 39 f. 5, $q$ - “Okinawa (Yayeyama)."

Polistes yayeyamensis [!]; Yasumatsu, 1935, Annotnes zool. jap. 15: 37 (Huka Naishi, Yonakuni Island). Yoshikawa, 1962, J. Biol., Osaka City Univ. 13: 41 (cat.) [author: Mats. 1926!].

Polistes jokahamae Rad. var. yayeyamae; Sonan, 1943, Trans. nat. Hist. Soc. Formosa 33: 477.

Polistes yokohamae yayeyamae Mats. 1926[!]; Yoshikawa, 1962, J. Biol., Osaka City Univ. 13: 4 i (cat.).

The specimens recorded below agree well with the original description. The yellow markings are more extensive than in any of the other subspecies. The distribution of this form deserves further study.

Southern Ryukyu Is.: 2 q Iriomote Island, 22 Aug. 1934, L. Gressitt (MCZ; ML).

Formosa: 1 \% Kilung (CAS; hebraeus det. C. D. Duncan). - It seems possible that the locality label of this specimen is incorrect.

Polistes rothneyi gressitti subsp. n. (fig. 14) $q-$ This form is very close to the subspecies in- habiting the Chinese mainland. The pronotum is entirely yellow, and the apical spots on the outer side of the mid and hind tibiae are usually somewhat larger.

The type is a female from Taihanroku, 1908 (ML); its yellow markings are slightly more extensive than those of the $q$ shown in fig. 13; the dark line at the upper margin of the clypeus is not connected with the line between the antennal insertions, and there is a small crescent-shaped spot in the upper posterior angle of the epicnemium of the mesepisternum.

Formosa: 1 q Taihanroku, 19-26 April 1908, H. Sauter (type, ML); 3 \& Hokuto, 23 Sept. 1927 (USNM); 1 운 Sozan, 29 June 1932, 2 \& Rokki, 14 June 1932 and 14 May 1934, 1 ㅇ Kuraru, 5 May 1934, 2 우 Chirifu, 19 May 1934, all L. Gressitt (MCZ); 1 q Puli (Hori), June 1954, Chin Hwei (BISH).

Polistes rothneyi hainanensis subsp. n. (fig. 15) ㅇ - Differs from the Formosan subspecies gressitti in the presence of a dark blotch in the lateral angle of the pronotum, and in the greater extent of the yellow colour on the first gastral tergite. As in some specimens of gressitti, the females have a large yellow spot on each side of the second gastral sternite, in front of the waved line.

Hainan Island: $1 q$ Grove 1.5 mile S. of Nodoa, June 1927, 5th Univ. Lingnan Exp. (type, MCZ); 3 \& Ta Hian, 14-15 June 1935, 4 Q Ta han, 15 June-3 Aug. 1935, 2 운 Nodoa, June-Aug. 1935, 191 ơ Fan Ta, 17 Aug. 1935, 1 \& Liamai, 1 o "5 Fing. Mts.", 10 June 1935, all $L$. Gressitt (paratypes, MCZ; 2 \%L).

Polistes rothneyi quatei subsp. n. (fig. 16)

o - Very similar to the Formosan subspecies gressitti, but supraclypeal area more extensively yellow, the yellow marks behind the ocelli not sharply separated from the yellow areas on temples (the dark lines running from top of eye to occiput are reddish and illdefined), lateral angles of pronotum with black and reddish blotch (in one specimen much reduced; perhaps sometimes absent), second gastral sternite black with yellowish mark in posterior lateral angles, legs generally darker, hind femora black with small yellow spot at apex on dorsal side, hind tibiae black.

Vietnam: 3 Kontum, N. of Pleiku, $550 \mathrm{~m}, 13$ May 1960, S. Quate (type and paratype, BISH; paratype, ML).

Polistes rothneyi robinsoni subsp. $\mathrm{n}$. (fig. 17)

$q$ - Looks like a dark form of subsp. grahami, but appears to differ constantly in the characteristic colour of the pronotum. The paratype from Gunong 

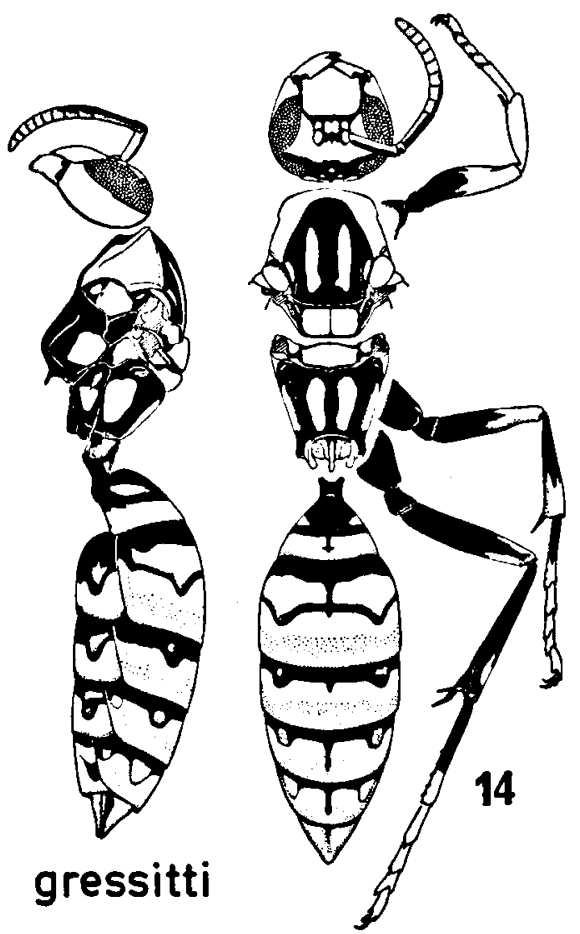

Fig. 14. P. rothneyi gressitti subsp. n., $O$ (Formosa, Sozan, paratype, MCZ).

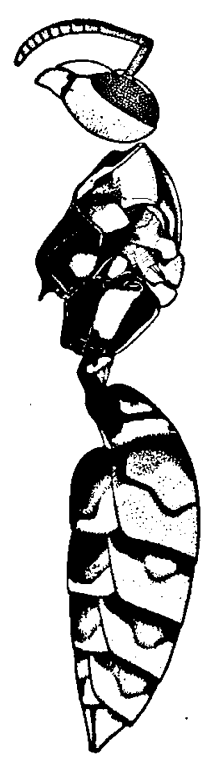

quatei

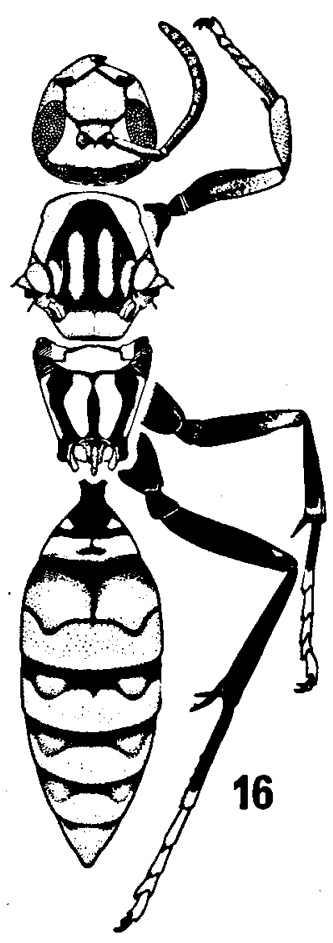

Fig. 16. P. rothneyi quatei subsp. n., 우 (Vietnam, Kontum, type, BISH).
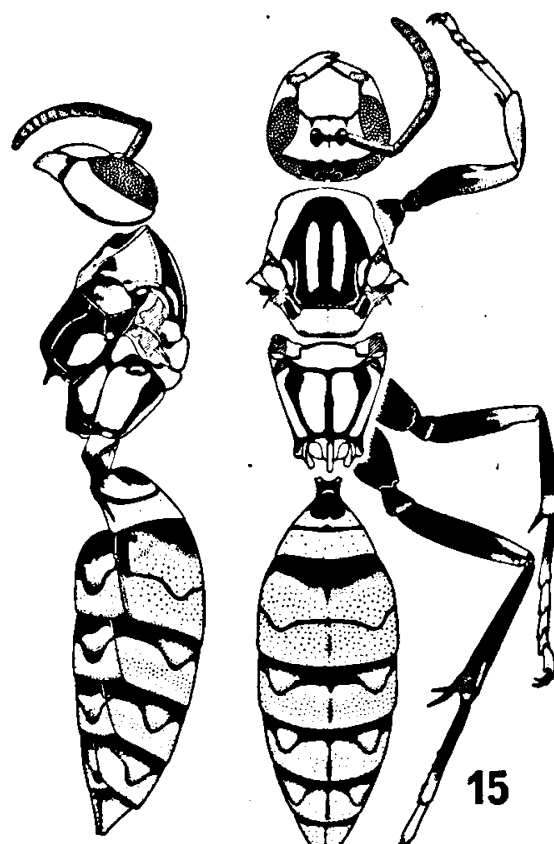

hainanensis

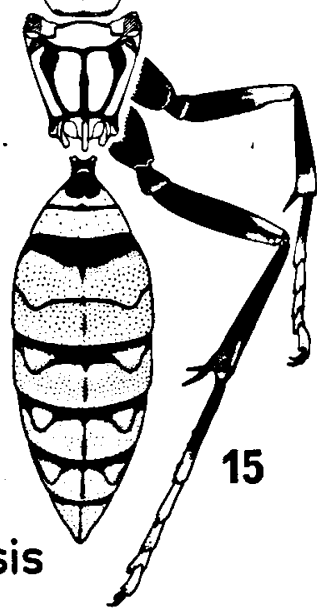

Fig. 15. P. rothneyi hainanensis subsp. $n$, ㅇ (Hainan, Nodoa, type, MCZ).
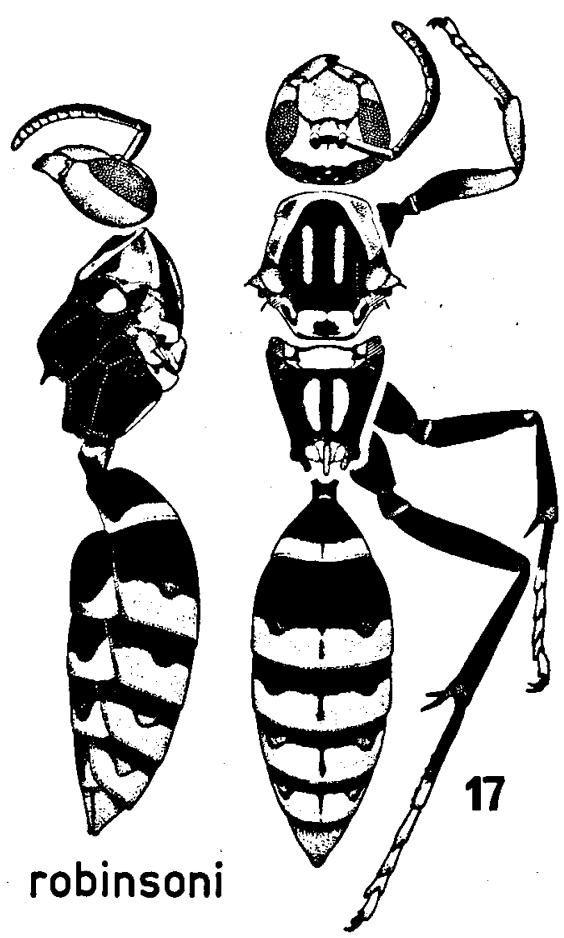

Fig. 17. $P$. rothneyi robinsoni subsp. n., $\uparrow$ (Malaya, Gunong Tahan, type, BM). 
Tahan differs from the type in having on each side of the second tergite a yellowish area in front of the waved line; the specimen from Ampang has a yellow spot on the metapleura and one on each side of the propodeum, the basal half of the second tergite is partly reddish.

of - Very similar to the female; face entirely brownish yellow; scutellum mainly black, with more or less complete yellow lines at the margins; fore and mid legs more extensively marked with pale brownish red (underside of coxae $I$ and spots on coxae II, the greater part of femora I, tibiae I entirely, underside of femora and tibiae II).

Malaya: Gunong Tahan near Perak, $2 q 5300-6000 \mathrm{ft}$., 17 June 1905, H. C. Robinson (type, BM; paratype, ML), 1 to Padang, $5550 \mathrm{ft}$., 15 Dec. 1922, 2 o Conical Hill, $5600 \mathrm{ft}$., 20-23 Dec. 1922, H. M. Pendlebury (BM; $1 \hat{\delta}$ ML). 1 ㅇ Selangor, Ampang Forest Reserve, Rimba, 3001200 ft., M. N. Penengat, Oct. 1920, H. C. Abraham (paratype, BM).

Polistes rothneyi engeli subsp. n. (fig. 18)

+ - Head dull brownish red, clypeus with faint yellowish tinge; the following parts black: a line at upper margin of clypeus, a spot between the anten- nae, a broad band across the ocelli, and the upper part of the occiput. Antennae black to fuscous above, only the last two segments slightly paler. In the type and two paratypes the red areas behind the eyes meet on vertex, in the other specimens the vertex is black, except for two transverse red marks behind the ocelli. Thorax, gaster and legs as shown in the figure. Wings distinctly darker than in most other subspecies, particularly the anterior half of the fore wing rather strongly infuscated. In the type the fourth sternite is less extensively black than in the paratype from which fig. 18 was made.

$\delta$ - Pattern similar to that of the female; face entirely reddish; mesosternum red in front of the epicnemial carinae; mid femora and tibiae black dorsally, red ventrally; fore legs red, with black line on under side of femora; hind legs black, except for tarsal segments 2-5, and the apex of the first, which are pale yellow.

I take pleasure in dedicating this subspecies to Prof. Dr. H. Engel on the occasion of his 70th birthday.

Sumatra: Deli, Toba Lake, 1 q Prapat, 31 Dec. 1954, J. van der Vecht (paratype, ML). Padang, 4 \& Alahan
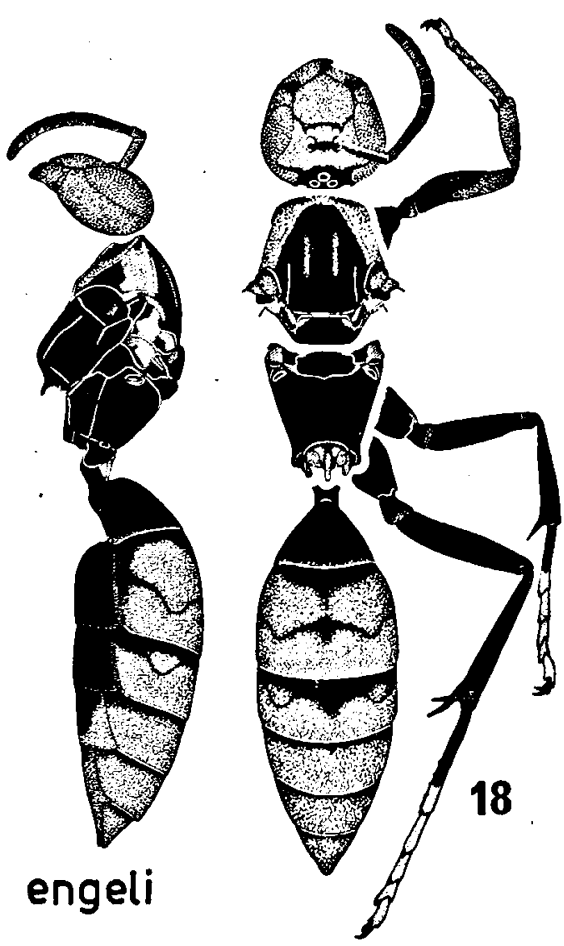

Fig. 18. $P$. rothneyi engeli subsp. n., $q$ (Sumatra, Alahan Pandjang, paratype, ML).

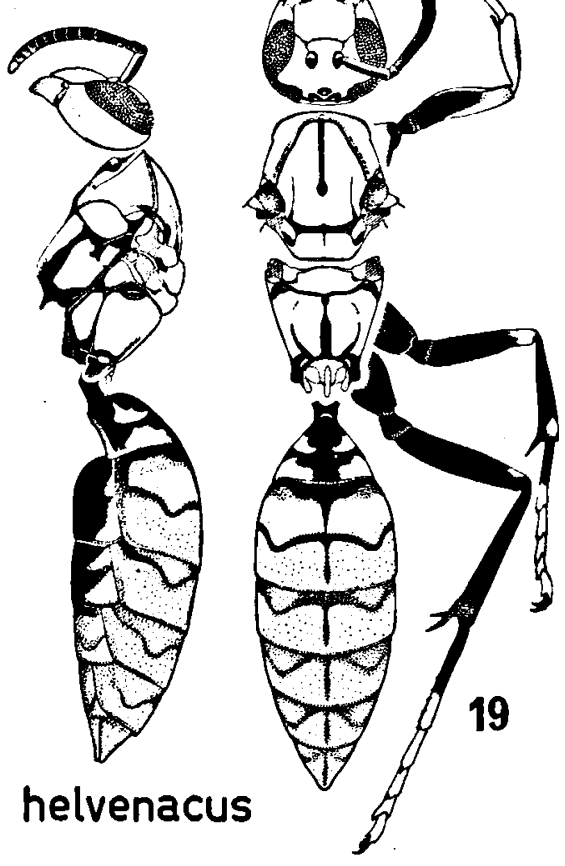

Fig. 19. P. rothneyi helvenacus subsp. n., Q (W. Java, Mt. Gedeh, type, ML). 
Pandjang, Sept. 1877, Sumatra Exp. 1877-'78 (type and paratypes, ML; 1 ㅇ BM); $3 \hat{\delta}$ West Sumatra, van Lansberge (allotype and paratypes, ML).

Polistes rothneyi helvenacus subsp. n. (fig. 19)

$\$$ - Yellow markings of vertex and mesoscutum even more extensive than in subsp. yayeyamae, but the first gastral tergite, the second and third sternites and the mid and hind legs considerably darker. Most of the yellow parts of the gaster have a more or less distinct brownish tinge. First gastral tergite as a rule with two pairs of yellow spots, but the posterior pair sometimes reduced or absent.

$\delta$ - Very similar to the $q$; vertex with transverse black band often covering the entire ocellar region; antennae entirely blackish dorsally; fore femora almost entirely brownish yellow; mid femora and tibiae with yellowish line on ventral side. First gastral tergite as a rule darker than in the $\$$, the posterior pair of yellow markings often much reduced or absent.

The type is a female from Mt. Gedeh, $1000 \mathrm{~m}$, Jan. 1935 (ML), the specimens recorded below are paratypes.
West Java: Mt. Salak near Bogor, 700-1000 m, 1 o 9 Febr. 1936, 1 o 17 May 1936, F. Dupont (ML); 3 ㅇ Tjiapus, Oct.-Nov. 1936, F. Dupont and C. J. H. Franssen (ML); 1 O Mt. Salak, $700 \mathrm{~m}, 7$ Nov. 1937, on Homalanthus populneus $\mathrm{O}$. K., J. van der Vecht (ML); 1 우 Pasir Leutik, 800 m, 3 Dec. 1939, J. van der Vecht (ML). Mt. Pantjar near Bogor, $400 \mathrm{~m}, 30 \mathrm{O}$ Jan., March, JulySept. 1936, 18 \& 22 ô 7 April 1937, F. Dupont and C. J. H. Franssen (MZB; ML; USNM; MCZ). Mt. Gedeh 2 o Tapos, $800 \mathrm{~m}$, June and Aug. 1933, 1 î Oct. 1932 J. van der Vecht (ML), 1 \% Tjibunar, 25 Nov. 1929, F. C. Drescher (P. perkinsi det. Schulthess), 2 do., 12 June 1949, J. van der Vecht (ML). Mt. Sanggabuana, 1 q 22 Dec. 1935, M. A. Lieftinck (ML). Djampang Tengah, 8 o 1933-8, Mrs. M. E. Walsh (MZB; ML), 6 \% do., 1934 and March 1935, Mrs. M. E. Walsh (MCZ), 4 \% Mt. Malang, 3000 ft., Febr. 1935, Mrs. M. E. Walsh, 1 \% do., $800 \mathrm{~m}$, Jan. 1940, M. A. Lieftinck (ML), 3 \% Mt. Tjisuru, 600-800 m, Oct.-Nov. 1933 and March 1935 , Mrs. M. E. Walsh (ML). Sukanegara, 700-1000 m, 1 \& 23-28 Dec. 1931, M. A. Lieftinck, 1 \& Febr. 1940 Indonesian coll. (ML). 1 \% Tjiandjur, Tjisereh (ML); 1 \& Radjamandala, 200-300 m, 15 Oct. 1939, J. Olthof (ML); 14 o Mt. Gedeh, Djampang, Mt. Malang, and Radjamandala, leg. Mrs. M. E. Walsh (BM).

Central Java: Mt. Slamet, 2 Baturraden, $800 \mathrm{~m}$, Dec. 1936, F. C. Drescher (MZB; ML).

\section{LITERATURE}

Bingham, C. T., 1897: Fauna of British India, including Ceylon and Burma. Hymenoptera I. 579 pp., 4 pls. London.

Cameron, P., 1900: Descriptions of new genera and species of Hymenoptera. Ann. Mag. nat. Hist. (7) 6, 410419.

Dover, C., 1925: Further Notes on the Indian Diplopterous Wasps. J. Proc. Asiat. Soc. Beng., n.s., 20 (1924), 289-305, 9 figs.

- 1929: Wasps and bees in the Raffles Museum, Singapore. Bull. Raffles Mus. 2, 43-70.

- 1931: The Vespidae in the F.M.S. Museums. J. fed. Malay St. Mus. 16, 251-260.
Sonan, J., 1943: On the genus Polistes in Formosa. Trans. nat. Hist. Soc. 33, 467-484.

TSUNEKI, K., 1957: Ecological Studies of Japanese Polistes wasps and their Taxonomy. The Life Study (Fukui) 3, 1-4 (in Japanese).

- 1962: The Aculeate Hymenoptera collected on the Island of Amami-Ohshima, the Riukius. The Life Study (Fukui) 6, 1-9.

YoshIKAWA, K., 1962: Introductory Studies on the Life Economy of Polistine Wasps. VI. Geographical Distribution and its Ecological Significances. J. Biol. Osaka City Univ. 13, 19-44. 